\title{
Selecting Folded Proteins from a Library of Secondary Structural Elements
}

\author{
James J. Graziano ${ }^{\ddagger}$, Wenshe Liu $\ddagger$, Roshan Perera ${ }^{\ddagger}$, Bernhard H. Geierstanger ${ }^{\star}, \S$, Scott A. \\ Lesley $^{\star}, \S, \ddagger$, and Peter G. Schultz ${ }^{*}, \S, \ddagger$ \\ Department of Chemistry and the Skaggs Institute for Chemical Biology, The Scripps Research \\ Institute, 10550 North Torrey Pines Rd., La Jolla, CA 92037 and Genomics Institute of the Novartis \\ Research Foundation, 10675 John Jay Hopkins Dr., San Diego, CA 92121 \\ *The Scripps Research Institute \\ $\S$ Genomics Institute of the Novartis Research Foundation
}

\begin{abstract}
A protein evolution strategy is described by which double-stranded DNA fragments encoding defined E. coli protein secondary structural elements ( $\alpha$-helices, $\beta$-strands and loops) are assembled semirandomly into sequences comprised of as many as 800 amino acid residues. A library of novel polypeptides generated from this system was inserted into an EGFP fusion vector and members screened by FACS to identify those polypeptides that fold into soluble, stable structures in vivo that comprised a subset of shorter sequences ( $\sim 60$ to 100 residues) from the semi-random sequence library. Approximately $10^{8}$ clones were screened by FACS, a set of 1149 high fluorescence colonies were characterized by $\mathrm{dPCR}$ and four soluble clones with varying amounts of secondary structure were identified. One of these is highly homologous to a domain of aspartate racemase from a marine bacterium (Polaromonas sp.) but is not homologous to any E. coli protein sequence. Several other selected polypeptides have no global sequence homology to any known protein, but show significant $\alpha$-helical content but limited dispersion in 1D NMR spectra, $\mathrm{pH}$ sensitive ANS binding and reversible folding into soluble structures. These results demonstrate that this strategy can generate novel polypeptide sequences containing secondary structure.
\end{abstract}

\begin{abstract}
Despite the large sequence diversity present in the proteomes of known organisms, most functional proteins characterized to date assume one of relatively few distinct folds ${ }^{1-5}$, suggesting that nature uses a limited number of stable, soluble folds relative to what is theoretically possible in protein sequence space. These folds likely represent the divergent products of a limited set of ancient protein folds. However, protein sequences that fold into stable, unique topologies but are not encoded by any sequenced genome may also exist. It may be possible to identify other stable folds that simply have not yet been sampled in the course of evolution by means of an artificial selection and molecular evolution process. Methods such as DNA shuffling ${ }^{6}$ which mimic the combinatorial diversity mechanism of the immune system are among the most efficient methods to modify or enhance protein activity. Unfortunately, the structural diversity generated in a library of shuffled homologues is relatively small ${ }^{7-11}$,
\end{abstract}

\footnotetext{
*To whom correspondence should be addressed. Telephone: 858-784-9273 (P.G.S.), 858-812-1551 (S.A.L.), or 858-812-1633 (B.H.G.). Fax: 858-784-9440 (P.G.S.), 858-812-1920 (S.A.L.), or 858-812-1746 (B.H.G.). E-mail: schultz@ scripps.edu; E-mail: slesley @ gnf.org; E-mail: bgeierstanger@gnf.org.

Novel proteins from secondary structural elements

SUPPORTING INFORMATION

Additional NMR data and complete ref 26 .
} 
although newer methods for random fragment assembly that overcome sequence homology requirements may lead to libraries with increased structural diversity ${ }^{12,13}$. Alternatively, natural or in vitro combinatorial assembly of distinct protein subunits (e.g., subdomains, exons, etc.) can create significant structural and functional diversity ${ }^{14-19}$. For example, the mammalian blood clotting proteins plasminogen, protein $\mathrm{C}$, urokinase and prothrombin are all derived from different combinations of 5 exons $^{14}$. Sequence and structural studies also suggest that many existing TIM barrel proteins evolved from the combinatorial assembly of subunits from more primitive eightfold $\beta \alpha$ barrels ${ }^{15,16}$. Other approaches for creating libraries of novel sequences that fold into native-like protein structures include the use of binary patterned residues designed around an existing known fold and the random assembly of cassettes composed of as few as three amino acid residues ${ }^{17,18}$. A more recent report details the use of cassettes of binary patterned residues around known protein motifs that are ultimately randomly assembled without fitting any designed folding constraint ${ }^{19}$. However, these latter methods have not yet yielded stable, novel folds under physiological conditions ${ }^{20}$.

Despite the considerable effort to identify or evolve new folds, only a limited number of distinct protein folds have been identified to date ${ }^{18}$. Here we describe a system for the synthesis of polypeptides with potentially novel folds in which existing sequence and structural data from bacterial proteins are used to assemble a pool of secondary structural elements ( $\alpha$-helices, $\beta$ strands and loops). These secondary structural elements are in turn recombined into a library of de novo sequences that may be screened or selected for folded proteins. Proteins that fold into a native state acquire measurable biophysical characteristics such as solubility, stable secondary structure, well-dispersed 1D NMR spectra indicative of packed side chains, and reversible two-state unfolding behavior. In this work, we chose to initially screen the library for polypeptides that are soluble in aqueous solution using a GFP fusion protein reporter that had been previously reported ${ }^{21}$. Indeed, several sequences with stable secondary structure are identified.

\section{MATERIALS \& METHODS}

\section{Library Construction}

All secondary structural elements in the shuffling pool were selected from unique $E$. coli proteins with structures on file in the Protein Data Bank (PDB) ${ }^{22}$. PDB files of these proteins were submitted to the program PROMOTIF ${ }^{23}$ and the output files annotating the elements of secondary structure and the primary sequence of each element, as well as loop primary sequence data from the Sloop database ${ }^{24}$, were submitted to DeCypher FrameSearch BLAST (Active Motif, Inc.) to obtain the $E$. coli nucleotide sequences encoding each element. Elements comprising fewer than 5 residues were not considered.

Oligonucleotide primers for each secondary structural element ( $\alpha$-helix, $\beta$-strand, loop) or chain terminator are comprised of an element or terminator specific sequence and a sequence that can hybridize to an intervening linker. The linkers for the different secondary structure elements are shown in Table 1.

Double-strand (ds) library elements were produced by either polymerase chain reaction (PCR) amplification from $E$. coli genomic DNA, or by single-strand (ss) oligonucleotide hybridization and extension reactions with Taq polymerase according to the following cycling parameters: $95^{\circ} \mathrm{C}$ for $3 \mathrm{~min}$ then 30 cycles of $95^{\circ} \mathrm{C}$ for $30 \mathrm{sec}, 56^{\circ} \mathrm{C}$ for $45 \mathrm{sec}, 72^{\circ} \mathrm{C}$ for $1 \mathrm{~min}$, followed by a final extension at $72^{\circ} \mathrm{C}$ for $5 \mathrm{~min}$. The products of these reactions were inserted into pBADThio (Invitrogen). DNA fragments encoding the secondary structural elements and the $5^{\prime}$ and 3 ' terminators were isolated from plasmid DNA by restriction digest with Bbs I alone (secondary structural elements) or Bbs I and AsiS I (terminators) followed by purification on a 2.5\% agarose gel. The purified fragments were combined into three pools and normalized to 
$250 \mu \mathrm{g} / \mathrm{ml}$ as follows: Pool 1: Helix/Loop/Strand fragments in 1:1:1 ratio; Pool 2: 5' terminators; and Pool 3: $3^{\prime}$ terminators. Ligation of the fragments into a library of oligomers was accomplished with a 100,000:100,000:1 ratio of Pools 1, 2 and 3, respectively, in $20 \mu \mathrm{l}$ reactions with T4 ligase in buffer containing $15 \%$ w/v PEG 6000 and $25 \mu \mathrm{M} \mathrm{ATP}$, at $20^{\circ} \mathrm{C}$ for 4 hours. Ligated products were amplified by PCR with primers specific for the invariant sequences of the $5^{\prime}$ and $3^{\prime}$ terminators (fwd: GAGCTCGTCGACCCATGGG, rev: GAGCTCGGATCCCGATCGG). The resulting fragments (between $400 \mathrm{bp}$ and $3000 \mathrm{bp}$ in size) were isolated and purified from a $1 \%$ agarose gel and were inserted into the screening vector JG1 (see below). Competent TOP10 cells (Invitrogen) were transformed by electroporation with $5 \mu \mathrm{g}$ aliquots of DNA and $500 \mu \mathrm{l}$ of competent cells, and were subsequently pooled. An aliquot was drawn to determine the average transformation efficiency for the library after one hour of recovery. The remaining pooled cells were pelleted and then re-suspended in $10 \mathrm{ml}$ of Luria-Bertani (LB) media supplemented with carbenicillin at a final concentration of $50 \mu \mathrm{g} / \mathrm{ml}$. This stock was used to inoculate 1 liter of LB containing $50 \mu \mathrm{g} / \mathrm{ml}$ carbenicillin and then cells were incubated overnight at $37^{\circ} \mathrm{C}$. Glycerol stocks were prepared and stored at $-70^{\circ} \mathrm{C}$.

The screening vectors JG1, JG1TEV, JG2 and JG2TEV were derived from a previously reported GFP fusion vector (GFP Folding Reporter ${ }^{21}$ ) and constructed as follows: the gene for EGFP was amplified from pEGFP-C1 (Clonetech) with the addition of upstream and downstream linkers added by overlap $\mathrm{PCR}^{25}$. The upstream linker includes an Nco I site, a 6Thio/6xHis expression tag, and Sal I and BamH I sites for inserting the shuffled fragment library in frame with EGFP downstream; the downstream linker incorporates a Pac I restriction site. This EGFP fragment was inserted into the Nco I/Pac I site of plasmid $\mathrm{pMH} 4^{26}$. The preexisting BamH I site in pMH4 was silenced by Quickchange mutagenesis (Stratagene). The downstream linker for JG1 and JG1TEV incorporate an additional C-terminal 6xHis tag. A Tobacco Etch virus (TEV) protease cleavage site (ENLYFL-G) was inserted between the BamH I site and the start codon of EGFP in JG1 and JG2 by overlap PCR mutagenesis to afford JG1TEV and JG2TEV, respectively. Vectors JG5 and JG5TEV were constructed from pMH4 as described above with the exception that EGFP is deleted, and the TEV site in JG5TEV is inserted between the 6-Thio/6x His expression tag and the Sal I restriction site.

\section{FACS Sorting}

E. coli cells for fluorescence activated cell sorting (FACS) were prepared based on the protocol of Santoro, et al. ${ }^{27}$. Induced cells containing the library were washed twice with 1x PBS buffer and then diluted into phosphate buffered saline (PBS) buffer to an $\mathrm{OD}_{600}$ of 0.1 , and stored on ice until sorting on a FACSVantage DiVa (Becton Dickinson). Selection criteria were set to sort positive cells into one of two tubes: high (GFPuv fluorescence $>80 \mathrm{RFU}$ ) or low fluorescence (10 RFU < GFPuv fluorescence < $80 \mathrm{RFU}$ ). Cells were recovered and amplified by overnight growth at $37^{\circ} \mathrm{C}$ in LB with $50 \mu \mathrm{g} / \mathrm{ml}$ carbenicillin and stored as glycerol stocks at $-70^{\circ} \mathrm{C}$. The sorted library was plated onto large format $(30 \mathrm{~cm} \times 30 \mathrm{~cm}$ square $)$ plates (Genetix) containing LB agar supplemented with $50 \mu \mathrm{g} / \mathrm{ml}$ carbenicillin and $0.02 \%$ arabinose at a dilution sufficient to produce well separated colonies. Fluorescent colonies were picked into LB media supplemented with $50 \mu \mathrm{g} / \mathrm{ml}$ carbenicillin, aliquoted into 96-well microtiter plates, and grown overnight at $37^{\circ} \mathrm{C}$.

\section{Library Screening}

Colonies ( $1 \mu \mathrm{l}$ of saturated cell culture from each well) were screened based on the presence and size of inserted library clones by multiplex colony dPCR ( 1 unit Taq polymerase, $0.2 \mathrm{mM}$ dNTPs, PCR buffer, $10 \mu \mathrm{M}$ Insert Verification primers (fwd:

CATCATCATCACGTGGTCGACCCATGGG and rev:

GCCAGCGGATCCCGATCGGCC). Up to three 96-well plates were combined in multiplex 
format per PCR screen. The results of the combined dPCR reaction were de-convoluted by identifying those wells with positive inserts of desirable length and repeating the reactions under the same conditions with cells from a single well per dPCR reaction. Target clones identified from insert screening were examined for detectable expression of soluble fluorescent protein. Clones in 96-well microplates were grown to $\mathrm{OD}_{600} 0.75$ to 1 in $\mathrm{LB}$ supplemented with $50 \mu \mathrm{g} / \mathrm{ml}$ carbenicillin at $37^{\circ} \mathrm{C}$, and induced by addition of $0.02 \%$ arabinose (final concentration) for 3 hours. At the 1.5 hour point a cocktail of ceftriaxone and cefotaxime (10 $\mu \mathrm{g} / \mathrm{mL}$ final concentration of each) was added to each well to facilitate cell lysis for the soluble protein screen described below. After 3 hours at $37^{\circ} \mathrm{C}$ the plates were centrifuged $(4000 \times \mathrm{g}$, $15 \mathrm{~min}$ ) and the supernatant divided and transferred to clear bottom, black 96-well microplates (Corning), as well as clear, flat-bottomed 96-well microplates (Falcon) or Maxisorp ELISA plates (Nunc). The black plates were read on a fluorescent plate reader (Molecular Devices) (ex: $488 \mathrm{~nm}$, em: $508 \mathrm{~nm}$ ). Screening of target clones for soluble protein was performed in parallel with small-scale expression testing by established protocols ${ }^{28}$. Briefly, $\beta$-galactosidase activity was determined by adding $50 \mu \mathrm{L}$ of 4 X Z-buffer $\left(180 \mathrm{mM} \mathrm{Na}_{2} \mathrm{HPO}_{4}, 120 \mathrm{mM}\right.$ $\mathrm{NaH}_{2} \mathrm{PO}_{4}, 30 \mathrm{mM} \mathrm{KCl}, 3 \mathrm{mM} \mathrm{MgSO}{ }_{4}, 150 \mathrm{mM} \beta$-mercaptoethanol) and $50 \mu \mathrm{l}$ of 4x ONPG (2.7 $\mathrm{mg} / \mathrm{ml} \mathrm{ONPG,} 60 \mathrm{mM} \mathrm{K}_{2} \mathrm{HPO}_{4}, 33 \mathrm{mM} \mathrm{KH}_{2} \mathrm{PO}_{4}, 8 \mathrm{mM}\left(\mathrm{NH}_{4}\right)_{2} \mathrm{SO}_{4}, 2 \mathrm{mM}$ sodium citrate) to the clear microplates containing $25 \mu \mathrm{l}$ of soluble lysate. Upon development of yellow color in positive control wells (EGFP), the reaction was quenched with $75 \mu \mathrm{l}$ of $1 \mathrm{M} \mathrm{Na}_{2} \mathrm{CO}_{3}$, $\mathrm{pH}$ 8. The $\mathrm{A}_{420 \mathrm{~nm}}$ and $\mathrm{A}_{550 \mathrm{~nm}}$ of each plate were recorded with the time of quenching. The final $75 \mu \mathrm{l}$ of lysate was bound overnight to the Maxisorp plates at $4^{\circ} \mathrm{C}$ after dilution to a final volume of $100 \mu \mathrm{l}$ with TBS (100 $\mathrm{mM}$ Tris, $\mathrm{pH} 7.5,150 \mathrm{mM} \mathrm{NaCl})$. The next day, buffer was removed and the plates were blocked with $1 \%(\mathrm{w} / \mathrm{v}) \mathrm{BSA}$ in TBS for 4 hours at $25^{\circ} \mathrm{C}$. The wells were subsequently washed with TBST (TBS with $0.1 \%$ v/v Tween-20), $100 \mu \mathrm{l}$ of NiHRP conjugate (KPL Labs) was then added at a dilution of $1: 2500$ for 1 hour at $25^{\circ} \mathrm{C}$, and the wells were again washed with TBST. $100 \mu 1$ of the HRP substrate (KPL Labs) was added and color was allowed to develop until the positive control (EGFP) well was deep blue. The reaction was quenched with $100 \mu \mathrm{l} 1 \mathrm{M} \mathrm{HCl}$ and the $\mathrm{A}_{420 \mathrm{~nm}}$ for each plate was recorded. Solubility scores were calculated and assigned by first weighting the Ni-HRP $\mathrm{A}_{420 \mathrm{~nm}}$ readings such that the mean was one order of magnitude greater than the mean of the $\beta$-galactosidase activity scores. The solubility score for each well was then calculated as the corrected Ni-HRP absorbance divided by the $\beta$-galactosidase activity score for the well.

\section{Polypeptide Expression \& Purification}

One liter flasks of each clone were grown to $\mathrm{OD}_{600 \mathrm{~nm}} 1$ at $37^{\circ} \mathrm{C}$ and induced by addition of arabinose $(0.02 \%)$. The temperature was then lowered to $18^{\circ} \mathrm{C}$ for 12 hours, and the cells were pelleted for storage or purification. Cells were ruptured by sonication in lysis buffer $(50 \mathrm{mM}$ Tris, $\mathrm{pH} 8,500 \mathrm{mM} \mathrm{NaCl}, 1 \mathrm{mM} \mathrm{MgCl} 2,5 \%$ v/v glycerol, $1 \mathrm{mM}$ TCEP, $1 \mathrm{mM}$ PMSF and $1 \mathrm{mM}$ pepstatin). The soluble fraction of the cell lysate was isolated by ultracentrifugation for one hour at $100,000 \times \mathrm{g}$. Purification of all proteins was carried out at $4^{\circ} \mathrm{C}$ using perfusion chromatography with Poros $20 \mathrm{MC}$ resin charged with $\mathrm{Ni}^{2+}$ ions on a BioCAD Sprint (Applied Biosystems) in $50 \mathrm{mM}$ Tris, $\mathrm{pH} 8.0,500 \mathrm{mM} \mathrm{NaCl}, 1 \mathrm{mM}$ TCEP. Proteins were eluted with a buffer containing $500 \mathrm{mM}$ imidazole, $50 \mathrm{mM}$ Tris, $500 \mathrm{mM} \mathrm{NaCl}, 1 \mathrm{mM}$ TCEP, pH 6.0. Eluted fractions were analyzed by SDS-PAGE and those containing the desired protein were pooled and exchanged into buffer A (10 mM Tris, $\mathrm{pH} 8,100 \mathrm{mM} \mathrm{NaCl}, 1 \mathrm{mM}$ TCEP). Desalted protein was subjected to size exclusion chromatography (SEC) on either Superdex $200 \mathrm{HR}$ (> $25 \mathrm{kD}$ ) or Superdex $75 \mathrm{HR}(<25 \mathrm{kD})$ in buffer A. Proteins subsequently digested with TEV protease were subjected to an additional round of purification as described below. Pooled fractions were again concentrated as before and final protein concentrations were determined both by Bradford assay (Pierce) and by $\mathrm{A}_{280 \mathrm{~nm}}$ measurement. For circular dichroism (CD) or NMR analysis proteins were buffer exchanged into PBS. 
To cleave the fusion proteins, TEV protease was added at a ratio of $0.2 \mu \mathrm{g}$ TEV protease per $\mu \mathrm{g}$ of protein, incubated for 4 hours at $25^{\circ} \mathrm{C}$ in $10 \mathrm{mM}$ Tris, $\mathrm{pH} 8.0,100 \mathrm{mM} \mathrm{NaCl}$, and then cooled to $4^{\circ} \mathrm{C}$ for 8 hours. Some fusion proteins required a 24-hour incubation at $4^{\circ} \mathrm{C}$. Proteolysis was monitored by SDS-PAGE. The cleaved target protein was purified by metal chelating chromatography and buffer exchange as described above.

\section{bisANS Binding}

Measurements of 5,5'-bis(8-anilino-1-naphthalenesulfonate (bisANS) binding to purified protein were performed with a fluorescence plate reader (Molecular Devices) as previously described $^{29}$. Stock solutions of $1 \mathrm{mM}$ bisANS in DMSO, $100 \mathrm{mM}$ potassium acetate buffer (pH 3.6, 4.6, and 5.6), $100 \mathrm{mM}$ potassium phosphate buffer (pH 6.6 and 7.6), and $100 \mathrm{mM}$ CHES buffer ( $\mathrm{pH} 8.6$ and 9.6) were prepared. Assay conditions were: $2 \mu \mathrm{M}$ protein, $20 \mathrm{mM}$ buffer, $100 \mathrm{mM} \mathrm{NaCl}, 2 \mathrm{mM}$ DTT, and $15 \mu \mathrm{M}$ bisANS. Bovine serum albumin (BSA) $(2 \mu \mathrm{M})$ served as the positive control: negative control samples contained no protein. Each target protein and control was assayed at $\mathrm{pH} 3.6,4.6,5.6,6.6,7.6,8.6$ and 9.6 in triplicate in a clear bottom, black 96-well microplate (Corning). Upon mixing, the reactions were incubated for $10 \mathrm{~min}$ at $25^{\circ} \mathrm{C}$ and then emission was measured from 440 to $550 \mathrm{~nm}$ (excitation at $395 \mathrm{~nm}$ ).

\section{Circular Dichroism}

CD measurements were carried out with an Aviv stopped flow CD spectrophotometer (model $202 \mathrm{SF}$ ) using $0.2 \mathrm{~cm}$ path length quartz cuvettes with $6 \mu \mathrm{M}$ samples in PBS buffer. Scans (200 to $250 \mathrm{~nm}$ ) were carried out at $0.5 \mathrm{~nm}$ increments and averaged for 5 scans per sample. Thermal denaturation of proteins was monitored by recording ellipticity at $222 \mathrm{~nm}$ with 3 scans per sample and temperature point. Thermal melts were performed from $20^{\circ} \mathrm{C}$ to $90^{\circ} \mathrm{C}$, and back to $20^{\circ} \mathrm{C}$, with a 2 min pause between measurements taken at $2^{\circ} \mathrm{C}$ intervals (dead band $0.1^{\circ} \mathrm{C}$, equilibration time $6 \mathrm{sec}$, averaging time $2 \mathrm{sec})$. Mean residue molar ellipticity $\left([\Theta]_{\mathrm{MRW}}\right)$ was calculated from the spectrophotometer output (mdeg) using the formula: $[\Theta]_{\mathrm{MRW}}=\Theta /(10 \times$ $\mathrm{c}_{\mathrm{r}} \times l$ ) where $\Theta$ is the $\mathrm{CD}$ signal (mdeg), $\mathrm{c}_{\mathrm{r}}$ is the mean residue molar concentration and $l$ is the path length of the cell in centimeters. CD data was used to compute relative proportions of secondary structure components as previously published ${ }^{30}$. Thermal melt data was fit to a four parameter sigmoidal model using SigmaPlot 2000 (SPSS, Inc.).

\section{D NMR}

NMR spectra were collected at $300 \mathrm{~K}$ on a Bruker Advance $600 \mathrm{MHz}$ instrument equipped with a ${ }^{1} \mathrm{H} /{ }^{13} \mathrm{C} /{ }^{15} \mathrm{~N}$-TXI CryoProbe (Bruker Biospin, Billerica, MA). Samples were typically in $500 \mu \mathrm{L}$ PBS, pH 7 with $50 \mu \mathrm{L} \mathrm{D}_{2} \mathrm{O}$ added as lock solvent. Samples of FK506 binding protein (FKBP12) in $20 \mathrm{mM}$ sodium phosphate buffer at pH 6.75 were measured in the presence of various amounts of urea. FKBP12 consists of a five-stranded $\beta$-sheet with a short $\alpha$-helix and connecting loops ${ }^{31}$. The protein has 124 amino acids including a His ${ }_{6} \mathrm{~N}$-terminal expression and purification tag, a molecular weight of $13757.6 \mathrm{Da}$. FKBP12 was expressed in E. coli and purified by Ni-affinity chromatograpy. Chemical shifts are relative to TSP (at $0.00 \mathrm{ppm}$ ) added as an internal standard or in a reference sample. $1 \mathrm{D}^{1} \mathrm{H}$ spectra were acquired using excitation sculpting with gradients for water suppression ${ }^{32}$. For samples in urea, an additional low power presaturation pulse was applied to suppress signals from the urea amino groups. The recycle delay was $2 \mathrm{~s}$ and 16384 complex points were collected over a sweep width of $13.97 \mathrm{ppm}$. NMR spectra were processed in TOPSPIN 1.3 (Bruker Biospin, Billerica, MA) applying an exponential line-broadening function of $1 \mathrm{~Hz}$ to all $1 \mathrm{D}$ spectra. 


\section{RESULTS \& DISCUSSION}

\section{Library Design}

Five primary elements, $\alpha$-helices, $\beta$-strands, loops, chain initators and chain terminators, were combined in a library to semi-randomly assemble polypeptides of up to 800 amino acids in length, which were then fused to EGFP protein for rapid screening of folded proteins ${ }^{21}$ in $E$. $\operatorname{coli}^{26}$. A set of $\alpha$-helices, $\beta$-strands and loops of five or more residues each was chosen from 190 nonredundant $E$. coli protein structures in the PDB to assemble a database of secondary structural elements. These proteins represent each of the major classifications of protein fold topologies (all $\alpha$, all $\beta, \alpha / \beta$, and $\alpha+\beta)^{22,33}$. The program PROMOTIF, which extracts and reformats PDB header information from each file into corresponding primary and secondary structural elements, was used to simplify construction of the database. The sLOOP database was used to identify the sequences of all loops in the pool, and further classify each loop as to the secondary structures it joins (i.e., helix to helix, strand to helix, etc.). The initial database of secondary structural elements contains 4389 helices ( 5 to 55 residues in length), 2054 strands ( 5 to 21 residues in length), and 246 loops (5 to 21 residues in length).

A library consisting of 605 helices, 328 strands, and 246 loops was assembled as a representative pool of secondary structural elements from the above database. To construct the library, the list of primary sequence elements in the database was converted to the associated E. coli DNA sequence using DeCypher FrameSearch BLAST (Active Motif, Inc.). Separate PCR reactions were used to generate dsDNA encoding each element of the library. Random recombination of these structural elements could lead to a large number of non-productive ligation products. For example, the possibility of fragment inversion during ligation is 50\% per fragment if blunt-end ligation is employed. As such, only 1 in $2^{n}$ (where $n$ is the number of fragments) ligation products would consist of structural elements entirely in the sense orientation. Therefore, short linkers, which incorporate a Bbs I Type II-S restriction enzyme recognition site that leaves 4-base sticky-end overhangs, were added to both ends of each library element. As a consequence, the sense strand orientation is maintained throughout fragment ligation. The sticky-end sequences were also designed such that a loop fragment was inserted between every helix and strand in the encoded polypeptide, and such that the loop fragments maintain the linkage orientation between helices and strands that existed in the source proteins (e.g., a loop that connects a helix at the amino-terminus and a strand at the carboxy-terminus would connect the same type of fragments in the library). As a result of this cloning strategy the linker sequences insert 3 non-native residues (GRA links helix to loop, VDH links loop to helix, LRP links strand to loop, and PAR links loop to strand) between each secondary structural element upon ligation. The linker residues were chosen based on a statistical propensity for joining a helix or a strand to a loop. Finally, chain terminator fragments were designed to incorporate restriction sites (a Sal I site at the $5^{\prime}$ terminus and a BamH I site at the $3^{\prime}$ terminus) for directional cloning of the ligated library, and to provide a means of modulating the sizes of the final ligation products.

\section{Library Construction \& Characterization}

Oligonucleotides incorporating the complementary Bbs I restriction sites were synthesized and 1248 separate PCR reactions were carried out to generate dsDNA encoding each element of the library. A schematic illustration of the library assembly and cloning is shown in Figure 1. The products of the PCR reactions were individually inserted into the $\mathrm{pBAD}$-Thio TOPO vector system as stocks. Although 13\% (164/1248) of the ligation reactions failed, the resulting library still had considerable diversity-DNA sequencing verified 96\% (1040/1084) of the remaining clones. Ligation reactions were performed on DNA fragments isolated from plasmid stocks using blunt ligation conditions (although the fragments all had sticky-end overhangs) to favor intermolecular over intramolecular ligation of compatible sticky-ends ${ }^{34}$. Identical 
stoichiometries of the helix, strand and loop encoding fragments were used in the ligation reactions. In addition, $5^{\prime}$ terminators were also used at the same stoichiometry to inhibit intramolecular ligation (by "capping" the extending polymer at one end). The other terminator fragment was included in the reaction at a 100,000-fold lower concentration. This ratio was empirically determined to give fragments of the desired length and composition of secondary elements.

Ligated fragments of the desired length ( $\geq 300 \mathrm{bp}$ ) were isolated by agarose gel electrophoresis and inserted into an EGFP fusion vector for screening and subsequent preliminary characterization. Library integrity was verified by analysis of 480 clones (from a library of 5.3 $\times 10^{9}$ elements) for insert size and the presence of the invariant terminator sequences. Additionally, 96 clones were fully sequenced. Insert sizes ranged from 200 to $2700 \mathrm{bp}$ with an average insert size of 300 to $400 \mathrm{bp} ; 74 \%$ (71 of 96) of the clones were the product of the desired ligation reaction with $5^{\prime}$ and $3^{\prime}$ terminators at the ends of library elements. The number of fragments per clone ranged from 5 to 17 with an average of 7 . In addition, 73\% (52 of 71) of these clones had point mutations focused predominantly at the ligation sites; $17 \%$ ( 9 of 52) were point mutations that caused frame shifts. The high frequency of mutations at the ligation junctions may result from incomplete ligation leaving nicked DNA that is further propagated as mutations at these sites by multiplexed PCR amplification of the ligated library. The introduction of point mutations at the connections of loops with helices or sheets was not expected to adversely affect the quality of the library since this phenomenon has been shown to occur naturally as examination of exon joints in spliced eukaryotic mRNA has revealed that these splice points are highly susceptible to mutation ${ }^{35}$.

\section{Library Screening}

Previously, a strategy was reported ${ }^{21}$ to screen for the expression of soluble proteins that involves fusion of the target protein to the N-terminus of GFP. Fusion proteins that are soluble and stable to proteolysis afford a high fluorescence signal, whereas insoluble proteins aggregate result in reduced signal from the sequestered GFP. This is a particularly attractive approach since a large library of GFP fusion polypeptides can be rapidly screened by FACS $\left(\sim 10^{8}\right.$ cells per hour throughput $)^{8,27,36,37}$. To this end, a modified GFP fusion vector was created in which a 6-Thio/6x His expression leader sequence was added upstream of the library cloning site to facilitate subsequent characterization of fluorescent clones ${ }^{26}$. Several variations of this vector were constructed to allow flexibility in the processing of the fusion proteins including the presence or absence of an additional C-terminal 6x His tag (JG1 or JG2, respectively), or the EGFP fusion protein (JG1/2 or JG5, respectively). Additionally, vectors were generated that contain a TEV protease cleavage site either between the cloning site and EGFP (JG1TEV and JG2TEV), or between the 6-Thio/6x His expression leader and the cloning site (JG5TEV).

The library of randomly ligated fragments was inserted into the EGFP fusion vector JG1, transformed into $E$. coli TOP 10 cells ( $\sim 10^{9}$ efficiency) and screened by FACS. Induced cells containing the library could be binned into two distinct fluorescent fractions labeled High Fluorescence (FACS GFPuv fluorescence gated $>80$ RFU) and Low Fluorescence (FACS GFPuv fluorescence gated $>10 \mathrm{RFU}$ and $<80 \mathrm{RFU}$ ). On the basis of $1 \times 10^{8}$ sorted cells, approximately $5.7 \times 10^{7}$ cells were identified as low fluorescence $(57 \%$ of the total cell population in the induced library) and $1.6 \times 10^{6}$ cells were identified as high fluorescence (1.6\% of the total). An initial characterization of the FACS sorted library was carried out by colony dPCR to verify the presence and relative size of the library insert. A set of 1149 high fluorescence colonies was picked from sorted clones plated on solid media. A total of 299 of 1149 clones with library inserts (26\%) screened by colony dPCR had inserts in the size range of 200 to $400 \mathrm{bp}$ with an overall average insert size of $500 \mathrm{bp}$ for all 1149 colonies screened. DNA sequencing of 24 of these clones showed 17 of 24 clones (71\%) were desired products 
of the ligation protocol. Twelve of the 17 inserts (70\%) contained point mutations focused at the ligation points.

Because of the large number of high fluorescence clone initially identified by FACS, additional assays amenable to high throughput analysis were used to identify those clones most likely to possess the characteristics of soluble, folded proteins. A semi-quantitative assay of fluorescence emission for each induced clone should correlate with the amount of soluble, folded protein (since GFP is not an environmentally sensitive fluorophore). Analysis of the 1149 clones with library inserts identified 44 clones (4\%) with measurable fluorescence (greater than the baseline of $1000 \mathrm{RFU}$ ) (Figure 2A). The level of measured fluorescence from this expression assay differs by 2 orders of magnitude over that measured in the FACS instrument due to the difference between the FACS assay (examining the fluorescence emission intensity from single cells) versus the microplate protein expression screen (examining the fluorescence emission of millions of cells per well simultaneously). A second assay, which combines a $\beta$-galactosidase ( $\beta$-gal) reporter assay for expression of misfolded protein with a nickel conjugated horse radish peroxidase (HRP) colorimetric assay that indicates the presence of soluble protein with $6 \mathrm{x}$ His tags ${ }^{28}$, was used to independently verify protein expression and solubility (Figure 2B). Twenty-two clones were found to have significant solubility scores; 14 of which were already identified in the fluorescence expression assay (Figure 2B). In addition, 18 clones that neither showed measurable fluorescence nor had significant solubility scores, but did have high Nickel-HRP assay scores, were considered for further characterization. Lesley, et al. ${ }^{28}$ had noted in their description of the solubility screen that it was more likely that false negative results due to high $\beta$-gal activity coupled with moderate or high Nickel-HRP response could fail to identify truly soluble proteins than the likelihood of a false negative resulting from high Nickel-HRP alone. These 70 clones were inserted into the appropriate expression and screening vectors for further characterization.

\section{Characterization of Selected Polypeptides}

Seven of these 70 clones that were expressed as non-fusion proteins with a 6-Thio/6x His tag (JG5 vector) produced sufficient protein to be visualized as Comassie-stained bands by SDSPAGE after a single nickel chelating FPLC purification step. Four of these seven clones were found in the fluorescence screen and all seven in the solubility screen, indicating that the solubility screen may be a better judge of soluble, folded protein. DNA sequencing of the seven clones showed that clones 5.6 and 5.12 were identical and that clone 5.24 contained a nonsense mutation. Therefore, clones 5.1, 5.6, 5.26, 5.29 and 5.31 were further characterized. Each of the five clones (5.1, 5.6, 5.26, 5.29 and 5.31) was between 198 and $273 \mathrm{bp}$ (66 and 91 amino acids, respectively) in length (Figure 4 and Table 2). The translated protein sequence of each clone was submitted to a BLAST search (blastp and blastn) and InterProScan to detect any DNA contamination from the experimental system ${ }^{38,39}$. The elements of the secondary structure library were easily identified by performing a blastn search optimized for short (25 bases or fewer), nearly identical sequences ${ }^{40}$. However, without this constraint, four of the five clones possess no global sequence homology to any known $E$. coli protein or any other protein sampled in the BLAST and InterProScan searches (Figure 3). Noteworthy is the fact that clone 5.6 has global sequence homology with a family of environmental bacterial aspartate racemases with $\mathrm{E}$ values from the blastp search of $2 \times 10^{-17}$. The a priori likelihood that the clone 5.6 sequence of assembled fragments exists in the library is $2.4 \times 10^{-17}$ (246 loops $\times 328$ strands $\times 246$ loops $\times 605$ helicies $\times 246$ loops $\times 328$ strands $\times 246$ loops) while there are only approximately $6 \times 10^{15}$ DNA molecules in the ligation reaction to start $(250 \mathrm{ug} / \mathrm{ml}$ total DNA corresponds to approximately $11 \mathrm{pmol}$ of each element which is $6 \times 10^{12}$ molecules $\times 1179$ fragments). It would seem unlikely that this sequence exists more than once in the final ligated library pool. Figure 3 displays an alignment of 5.6 with its 5 closest homologues. The BLAST search of clone 5.6 identified fragments of the gene that exist in the E. coli fragment library, 
but not a single E. coli gene with detectable homology. Therefore the possibility of environmental contamination is unlikely. Conversely, the search identified highly homologous sequences from several environmental bacteria, though none are identical. The closest related sequence (by phylogeny) is from a psychrophillic bacteria (Polaromonas sp.) which is highly unlikely to be a contaminant in our more temperate laboratory. Thus clone 5.6 demonstrates that libraries created from randomly recombined secondary structural elements can at a minimum recapitulate known protein structural domains.

The protein sequences of clones 5.1, 5.6, 5.26, 5.29 and 5.31 including the expression and purification tag are listed in Figure 4. With the exception of clone 5.31, all proteins have predicted $\mathrm{pI}$ values > 9.6; clone 5.31 is the only neutrally charged protein in the group (Table 2). Compared to the amino acid composition expected from the codon usage in E. coli (http://cmr.tigr.org/tigr-scripts/CMR/shared/Menu.cgi?menu=genome), clone 5.1 and 5.29 contain disproportional numbers of Arg, Pro and Ser residues. Similarly, clones 5.6 and 5.26 are rich in Ala and Arg while 5.31 is rich in Pro and Gly.

The biophysical properties of all five clones (5.1, 5.6, 5.26, 5.29 and 5.31) were further characterized by a number of methods including bisANS binding, CD spectrometry, thermal denaturation and 1-D NMR ${ }^{19,41-44}$. The fluorescent dye 5, 5'-bis(8-anilino-1-

naphthalenesulfonate) (bisANS), which binds to exposed or accessible hydrophobic surfaces of proteins ${ }^{45}$, has been used as a probe of protein folding. BisANS fluorescence increases upon binding to unfolded as well as molten globule proteins ${ }^{46}$. Environmental sensitivity of bisANS binding implies structural fluctuations or unfolding transitions, whereas insensitivity to changes in $\mathrm{pH}$, temperature or denaturant infers either a lack of significant secondary or tertiary structure (random coil) or a highly stable compact tertiary structure. Therefore the binding of bisANS to clones 5.1, 5.6, 5.26, 5.29 and 5.31 was measured as a function of $\mathrm{pH}$. At $\mathrm{pH}$ 7.0, the maximum fluorescence was at $495 \mathrm{~nm}$ for all of the proteins (Figure 5); this wavelength was therefore used to monitor emission intensity when the samples were assayed from $\mathrm{pH} 3.6$ to $\mathrm{pH}$ 9.6. The bisANS binding data showed marked differences in $\mathrm{pH}$-sensitivity for the different clones. All clones showed a significant increase in fluorescence at acidic $\mathrm{pH}$ with clone 5.26 having the highest degree of change in ANS binding. Therefore, it is likely that these clones are undergoing $\mathrm{pH}$ induced structural changes.

The far-UV CD spectra ( $250 \mathrm{~nm}$ to $200 \mathrm{~nm}$ ) of clones 5.1, 5.6, 5.26, 5.29 and 5.31 were then determined to assess the presence of secondary structure in the clones. Clone 5.29 lacks regular secondary structure ( $0 \%$ helical content) consistent with a random coil topology. This data correlates well with the low degree of bisANS binding upon $\mathrm{pH}$ induced unfolding. For the other four clones, CD spectra revealed distinct minima at $208 \mathrm{~nm}$ and $222 \mathrm{~nm}$, corresponding to varying degrees of largely $\alpha$-helical secondary structure. Calculation of the secondary structure for clones 5.1, 5.6, 5.26 and 5.31 (Figure 6A) from the CD data indicated they have $40 \%$ (5.1), 29\% (5.6), 15\% (5.26) and 47\% (5.31) $\alpha$-helical structure ${ }^{30}$. The experimentally determined helical content appears to contrast with the expected fraction of helical content based on the secondary structures of the initial library elements (assuming the fragments adopt similar secondary structures in the selected polypeptides). The latter values predict that the polypeptides would be $22 \%$ (5.1), $6 \%$ (5.6), $23 \%$ (5.26) and $17 \%$ (5.31) $\alpha$-helical. Secondary structure predictions with AGADIR $^{47}$ suggest there is little to no $\alpha$-helical structure in any of the polypeptide sequences. AGADIR predicts $1.2 \%(5.1), 7.8 \%(5.6), 4.8 \%(5.26)$ and $0.3 \%$ (5.31) $\alpha$-helical content which does not correlate to either the CD data or the estimated percentage of $\alpha$-helical content based on the original fragment origins (see below). The estimates based on the fragment origins would seem to correlate more closely with the CD data when all three estimates are examined together suggesting that some degree of residual secondary structure may be retained by the fragments outside the context of their native sequence. The small dataset presented here is insufficient to draw any conclusions with regard 
to the correlation of structural propensities to the polypeptides in solution. The lack of correlation between the fragment origins and the structure they appear to assume in the selected polypeptides is not too surprising since it is well known that primary sequence is not the sole determinant of secondary structure formation ${ }^{52-56}$. Notably, although the bisANS binding data suggests that clone 5.26 is the most conformationally sensitive to $\mathrm{pH}$ changes, it displays the least degree of helical character of the four remaining clones.

The $\alpha$-helical character of clones 5.1, 5.6, 5.26 and 5.31 provided a means to study unfolding by monitoring the change in ellipticity at $222 \mathrm{~nm}$ as a function of temperature (Figure 6B). For Clone 5.1 and 5.6 the ellipticity decreased to 37 and $35 \%$ of the maximal value at $20^{\circ} \mathrm{C}$. The changes were much smaller for clone 5.26 and 5.31 with 84 and $80 \%$ of the CD signal remaining at $90^{\circ} \mathrm{C}$. Clones 5.1, 5.6 and 5.31 were found to unfold reversibly (Figure 6C and D). $\mathrm{T}_{u}$ (midpoint temperature for unfolding) and $\Delta \mathrm{G}_{u}$ (free energy of folding) values (Figure 6C and Table 2) were determined by fitting the reversible denaturation data to a five-parameter model via non-linear regression. Values of $\Delta \mathrm{G}_{u}$ ranged from 3.6 to $4.1 \mathrm{kcal} / \mathrm{mol}$ and are similar to other de novo "synthetic proteins"17,48-50. Clones 5.1, 5.6 and 5.31 have near superimposable unfolding and refolding profiles that can be modeled accurately with a two-state transition suggesting cooperative unfolding. Clones 5.1, 5.6 and 5.31 may therefore have some tertiary interactions. In contrast, clone 5.26 unfolded irreversibly with little change in ellipticity as temperature was lowered after initial unfolding (Figure 6B and D). Both 5.26 and 5.31 retained a large proportion of the CD signal even at the highest temperature. Common to all four clones is the high helicity that cannot be explained by simple addition of the expected CD signal from individual elements of secondary structure and is also substantially higher than the $\alpha$-helcial content predicted by AGADIR.

The chemical shift dispersion of the 1-D NMR spectra of proteins is a qualitative measure of protein folding and tertiary packing of protein side chains ${ }^{60-62}$. The 1-D NMR spectra of clones 5.6, 5.26 and 5.31 measured at neutral $\mathrm{pH}$ are shown in Figure 7A, B and C, respectively. Data collection for clone 5.1 and 5.29 proved difficult due to insufficient quantities of concentrated, soluble protein. The NMR spectra of the three other clones are different from each other but display little dispersion in both the amide (6 to $10.5 \mathrm{ppm})$ and methyl proton regions ( -0.5 to $2.5 \mathrm{ppm}$ ) compared to the spectra of FKBP12, a $13.9 \mathrm{kDa}$, compact predominantly $\beta$-sheet protein (Figure 7D) ${ }^{31}$. Consistent with its high $\alpha$-helical content as measured by CD, the amide resonances of clone 5.31 (Figure 7C) show less dispersion than the other two clones. Significant line broadening is observed for the amides of clone 5.26 (Figure 7B) and to some extent also for clone 5.6 (Figure 7A), suggesting conformational exchange rather than a highly stable secondary and tertiary structure. This conclusion is supported by the observation of only limited protection of amide resonances from solvent exchange in 1D experiments with presaturation of the solvent (Supplemental Figure S1). Addition of solid urea to a sample of 5.26 induced only small chemical shift changes (Figure S2) and different sets of resonances for folded and unfolded protein (as is the case for FKBP12; Figure S3) cannot be identified. The NMR spectra of the selected clones are similar to that of FKBP12 unfolded in 6.7 M urea (Figure 7E) but CD strongly supports stable, helical secondary structures beyond what would be expected based on the amino acid sequence alone. The selected clones should therefore not be considered viewed as "native-like" proteins but rather "molten globule-like" 46 perhaps as an intermediary stage in the evolution from a random assembly of secondary structural elements towards a compact stable protein. The selection process utilized in this study identified successful combinations of secondary structural elements which could be combined to form a soluble assembly of secondary structure. Further mutagenesis with an alternate selection specific to promoting the formation and stabilization of a hydrophobic would be necessary to achieve the next stage of forming a compact "native-like" protein. 
By selecting elements from known folded proteins that combine into novel polypeptide sequences, we have identified a number of soluble polypeptides after screening only a small fraction of the first generation library $\left(0.0001 \% ; 1149\right.$ clones from a library of $\left.\sim 10^{9}\right)$. Of the 1149 clones screened 4 sequences $(0.3 \%$; clones 5.1, 5.6, 5.26 and 5.31) were identified as proteins with significant amounts of secondary structure. Assuming that cell sorting and FACS analysis were not statistically biased, our sampling would suggest that the library should contain on the order of 2,000,000 novel proteins with significant secondary structure ( 3 of the 4 clones represented sequences without any homologs). This is certainly an overestimate as amplification of the library prior to cloning and transformation would have slightly biased the diversity by introduction of duplicate sequences. However, the total number of unique sequences in this library with the desired characteristics appears to be significant nonetheless. Previous theoretical estimations by Lau $\&$ Dill ${ }^{51}$ predict that the fraction of protein sequence space represented by those sequences (average chain length 70 residues) that fold into stable, native structures to be between $10^{-4}$ and $10^{-7}$, suggesting that the system described here is more efficient for creating novel folded protein sequences. A previous report describing libraries of similar size constructed from semi-random assembly of secondary structure elements identified only sequences that required high ionic strength or chaotropic agents to induce measurable secondary structure and native-like protein character ${ }^{19}$. The secondary structure elements used in the creation of those libraries were based on binary patterning instead of native sequences, suggesting that the use of native sequences imparts a greater degree of secondary structure upon the product polypeptide sequences. Most surprising was our identification of a sequence (5.6) that largely recapitulates a conserved domain from species of environmental bacteria without any homologous sequences within the E. coli genome. This gives rise to hope that libraries constructed from elements of secondary structure may improve the likelihood of identifying novel proteins possessing detectable activity over the use of random sequences.

\section{CONCLUSIONS}

We have described an experimental system by which secondary structure elements are combinatorially assembled into a library that contains soluble proteins with significant secondary structure. Most noteworthy, the initial screen of this library identified one protein (clone 5.6) that is highly homologous to the N-terminal domain of a family of known proteins. Three other proteins were identified that had no homologous sequence in any of the available genomes. The high rate $(0.3 \%)$ of identifying folded proteins by screening only a small proportion of our library suggest that the semi-random assembly of secondary structural elements results in a significant likelihood of identifying novel protein sequences. Additional optimization of the library construction and screening protocols, as well as inclusion of additional structural elements (such as independently folding domains and sequences that can function as folding nuclei ${ }^{52,53}$ ) may further improve the number and quality of proteins selected from the screens. Alternatively, the generation of additional point mutations in the library by iterative rounds of error-prone PCR and/or DNA shuffling might be expected to lead to improved packing or hydrogen bonding interactions between the secondary structural elements. It should also be possible to screen the next generation libraries for functional activities such as heme and DNA binding ${ }^{54-56}$ and esterase activity ${ }^{57}$.

\section{Supplementary Material}

Refer to Web version on PubMed Central for supplementary material.

\section{ACKNOWLEDGEMENT}

The authors thank Heath Klock and Drs. Jeff Kelly, Ray Stevens, Dave Goodin, Jack Johnson, Dave Wemmer, Glen Spraggon, Andreas Kreusch, Chris Lee and Mike DiDonato for helpful discussion and use of resources. Additionally, 
the authors thank Alan Saluk and Cheryl Kim for FACS assistance, and Ted Foss and Luke Wiseman for assistance with CD measurements. We thank Susan Crown for samples of FKBP12 protein. This work was supported by NIH grant 5R01 GM56528.

\section{Abbreviations}

EGFP, enhanced green fluorescent protein; bisANS, 4,4'-Bis(1-anilino-naphthalene 8sulfonate); NMR, nuclear magnetic resonance; $\mathrm{CD}$, circular dichroism; FACS, fluorescence activated cell sorting.

\section{REFERENCES}

(1). Greene LH, Lewis TE, Addou S, Cuff A, Dallman T, Dibley M, Redfern O, Pearl F, Nambudiry R, Reid A, Sillitoe I, Yeats C, Thornton JM, Orengo CA. Nucleic Acids Res 2007;35:D291-7. [PubMed: 17135200]

(2). Orengo CA, Sillitoe I, Reeves G, Pearl FM. J Struct Biol 2001;134:145-65. [PubMed: 11551176]

(3). Thornton JM, Orengo CA, Todd AE, Pearl FM. J Mol Biol 1999;293:333-42. [PubMed: 10529349]

(4). Wolf YI, Brenner SE, Bash PA, Koonin EV. Genome Res 1999;9:17-26. [PubMed: 9927481]

(5). Zeldovich KB, Berezovsky IN, Shakhnovich EI. J Mol Biol 2006;357:1335-43. [PubMed: 16483605]

(6). Stemmer WP. Nature 1994;370:389-91. [PubMed: 8047147]

(7). Crameri A, Raillard SA, Bermudez E, Stemmer WP. Nature 1998;391:288-91. [PubMed: 9440693]

(8). Crameri A, Whitehorn EA, Tate E, Stemmer WP. Nat Biotechnol 1996;14:315-9. [PubMed: 9630892]

(9). Kikuchi M, Harayama S. Methods Mol Biol 2002;182:243-57. [PubMed: 11768970]

(10). Kurtzman AL, Govindarajan S, Vahle K, Jones JT, Heinrichs V, Patten PA. Curr Opin Biotechnol 2001;12:361-70. [PubMed: 11551464]

(11). Zhao H, Arnold FH. Nucleic Acids Res 1997;25:1307-8. [PubMed: 9092645]

(12). Bittker JA, Le BV, Liu DR. Nat Biotechnol 2002;20:1024-9. [PubMed: 12219078]

(13). Bittker JA, Le BV, Liu JM, Liu DR. Proc Natl Acad Sci U S A 2004;101:7011-6. [PubMed: 15118093]

(14). Harayama S. Trends Biotechnol 1998;16:76-82. [PubMed: 9487735]

(15). Lang D, Thoma R, Henn-Sax M, Sterner R, Wilmanns M. Science 2000;289:1546-50. [PubMed: 10968789]

(16). Nagano N, Orengo CA, Thornton JM. J Mol Biol 2002;321:741-65. [PubMed: 12206759]

(17). Davidson AR, Sauer RT. Proc Natl Acad Sci U S A 1994;91:2146-50. [PubMed: 8134363]

(18). Reidhaar-Olson JF, Sauer RT. Science 1988;241:53-7. [PubMed: 3388019]

(19). Matsuura T, Ernst A, Pluckthun A. Protein Sci 2002;11:2631-43. [PubMed: 12381846]

(20). Hecht MH. Proc Natl Acad Sci U S A 1994;91:8729-30. [PubMed: 8090714]

(21). Waldo GS, Standish BM, Berendzen J, Terwilliger TC. Nat Biotechnol 1999;17:691-5. [PubMed: 10404163]

(22). Berman HM, Westbrook J, Feng Z, Gilliland G, Bhat TN, Weissig H, Shindyalov IN, Bourne PE. Nucleic Acids Res 2000;28:235-42. [PubMed: 10592235]

(23). Hutchinson EG, Thornton JM. Protein Sci 1996;5:212-20. [PubMed: 8745398]

(24). Burke DF, Deane CM, Blundell TL. Bioinformatics 2000;16:513-9. [PubMed: 10980148]

(25). Hayashi N, Welschof M, Zewe M, Braunagel M, Dubel S, Breitling F, Little M. Biotechniques 1994;17:310, 312, 314-5. [PubMed: 7980934]

(26). Lesley SA, et al. Proc Natl Acad Sci U S A 2002;99:11664-9. [PubMed: 12193646]

(27). Santoro SW, Schultz PG. Methods Mol Biol 2003;230:291-312. [PubMed: 12824591]

(28). Lesley SA, Graziano J, Cho CY, Knuth MW, Klock HE. Protein Eng 2002;15:153-60. [PubMed: 11917152]

(29). Offredi F, Dubail F, Kischel P, Sarinski K, Stern AS, Van de Weerdt C, Hoch JC, Prosperi C, Francois JM, Mayo SL, Martial JA. J Mol Biol 2003;325:163-74. [PubMed: 12473459] 
(30). Greenfield N, Fasman GD. Biochemistry 1969;8:4108-16. [PubMed: 5346390]

(31). Michnick SW, Rosen MK, Wandless TJ, Karplus M, Schreiber SL. Science 1991;252:836-9. [PubMed: 1709301]

(32). Hwang TL, Shaka AJ. Journal of Magnetic Resonance, Series A 1995;112:275-9.

(33). Orengo CA, Flores TP, Taylor WR, Thornton JM. Protein Eng 1993;6:485-500. [PubMed: 8415576]

(34). Upcroft P, Healey A. Gene 1987;51:69-75. [PubMed: 3596240]

(35). Gilbert W, de Souza SJ, Long M. Proc Natl Acad Sci U S A 1997;94:7698-703. [PubMed: 9223251]

(36). Becker S, Schmoldt HU, Adams TM, Wilhelm S, Kolmar H. Curr Opin Biotechnol 2004;15:3239. [PubMed: 15296929]

(37). Winson MK, Davey HM. Methods 2000;21:231-40. [PubMed: 10873477]

(38). Altschul SF, Madden TL, Schaffer AA, Zhang J, Zhang Z, Miller W, Lipman DJ. Nucleic Acids Res 1997;25:3389-402. [PubMed: 9254694]

(39). Quevillon E, Silventoinen V, Pillai S, Harte N, Mulder N, Apweiler R, Lopez R. Nucleic Acids Res 2005;33:W116-20. [PubMed: 15980438]

(40). Altschul SF, Gish W, Miller W, Myers EW, Lipman DJ. J Mol Biol 1990;215:403-10. [PubMed: 2231712]

(41). Betz SF, Raleigh DP, DeGrado WF. Current opinion in structural biology 1993;3:601-610.

(42). Davidson AR, Lumb KJ, Sauer RT. Nat Struct Biol 1995;2:856-64. [PubMed: 7552709]

(43). Hecht MH, Das A, Go A, Bradley LH, Wei Y. Protein Sci 2004;13:1711-23. [PubMed: 15215517]

(44). Kuhlman B, Dantas G, Ireton GC, Varani G, Stoddard BL, Baker D. Science 2003;302:1364-8. [PubMed: 14631033]

(45). Smoot AL, Panda M, Brazil BT, Buckle AM, Fersht AR, Horowitz PM. Biochemistry 2001;40:4484-92. [PubMed: 11284705]

(46). Goto Y, Fink AL. Biochemistry 1989;28:945-52. [PubMed: 2496758]

(47). Munoz V, Serrano L. Biopolymers 1997;41:495-509. [PubMed: 9095674]

(48). Makhatadze GI, Privalov PL. Adv Protein Chem 1995;47:307-425. [PubMed: 8561051]

(49). Privalov PL. Adv Protein Chem 1979;33:167-241. [PubMed: 44431]

(50). Wei Y, Liu T, Sazinsky SL, Moffet DA, Pelczer I, Hecht MH. Protein Sci 2003;12:92-102. [PubMed: 12493832]

(51). Lau KF, Dill KA. Proc Natl Acad Sci U S A 1990;87:638-42. [PubMed: 2300551]

(52). Dinner AR, Sali A, Smith LJ, Dobson CM, Karplus M. Trends Biochem Sci 2000;25:331-9. [PubMed: 10871884]

(53). Dobson CM. Nat Rev Drug Discov 2003;2:154-60. [PubMed: 12563307]

(54). Looger LL, Dwyer MA, Smith JJ, Hellinga HW. Nature 2003;423:185-90. [PubMed: 12736688]

(55). Rojas NR, Kamtekar S, Simons CT, McLean JE, Vogel KM, Spiro TG, Farid RS, Hecht MH. Protein Sci 1997;6:2512-24. [PubMed: 9416601]

(56). Mossing MC, Bowie JU, Sauer RT. Methods Enzymol 1991;208:604-19. [PubMed: 1838136]

(57). Wei Y, Hecht MH. Protein Eng Des Sel 2004;17:67-75. [PubMed: 14985539]

(58). Thompson JD, Higgins DG, Gibson TJ. Nucleic Acids Res 1994;22:4673-80. [PubMed: 7984417]

(59). Gouet P, Robert X, Courcelle E. Nucleic Acids Res 2003;31:3320-3. [PubMed: 12824317] 
A

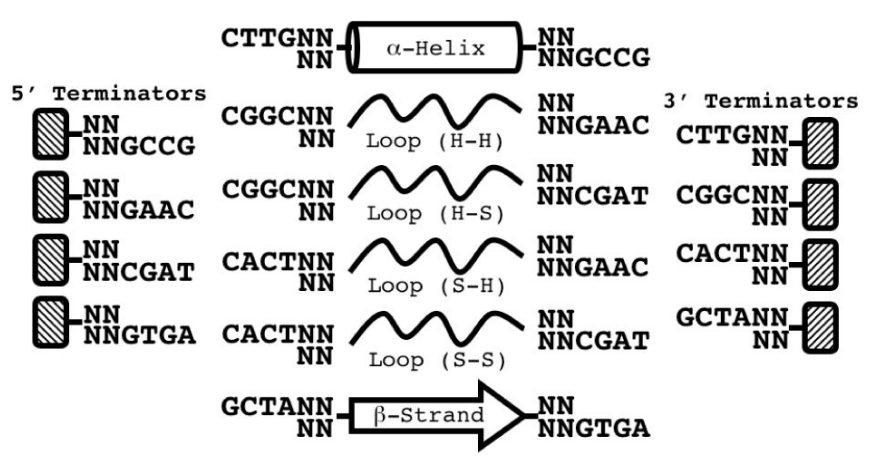

B
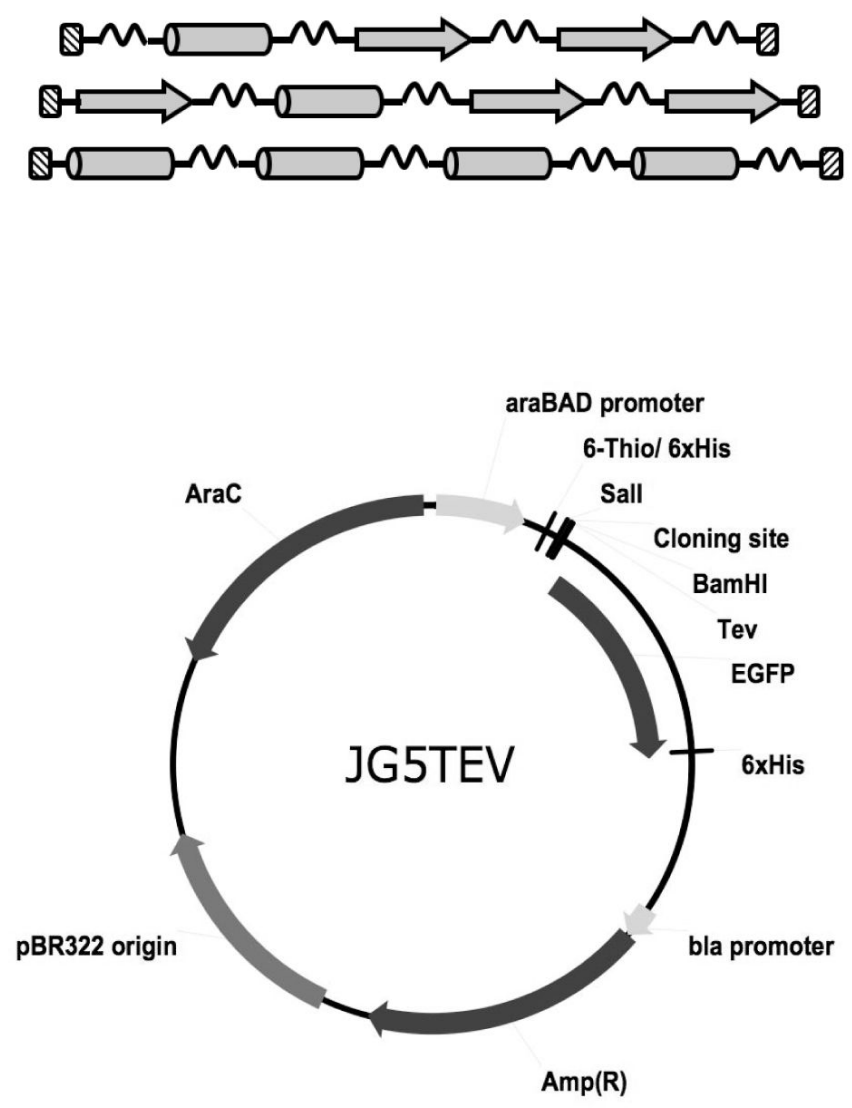

Figure 1.

Schematic representation of the library synthesis scheme. (A) Secondary structural elements are identified and oligoDNA primers are designed to add Bbs I restriction sites unique to the $5^{\prime}$ and $3^{\prime}$ ends of each element family. Additional synthetic $5^{\prime}$ and $3^{\prime}$ terminators include complementary Bbs I restriction sites on one end. (B) The secondary structure elements are amplified and then digested, purified, and ligated in a single reaction. The ligated, polymerized library is PCR amplified and gel purified for cloning into the EGFP fusion vector for FACS. (C) Vector map of the vector JG5 for protein expression and characterization (in the absence of the EGFP fusion protein). 
A

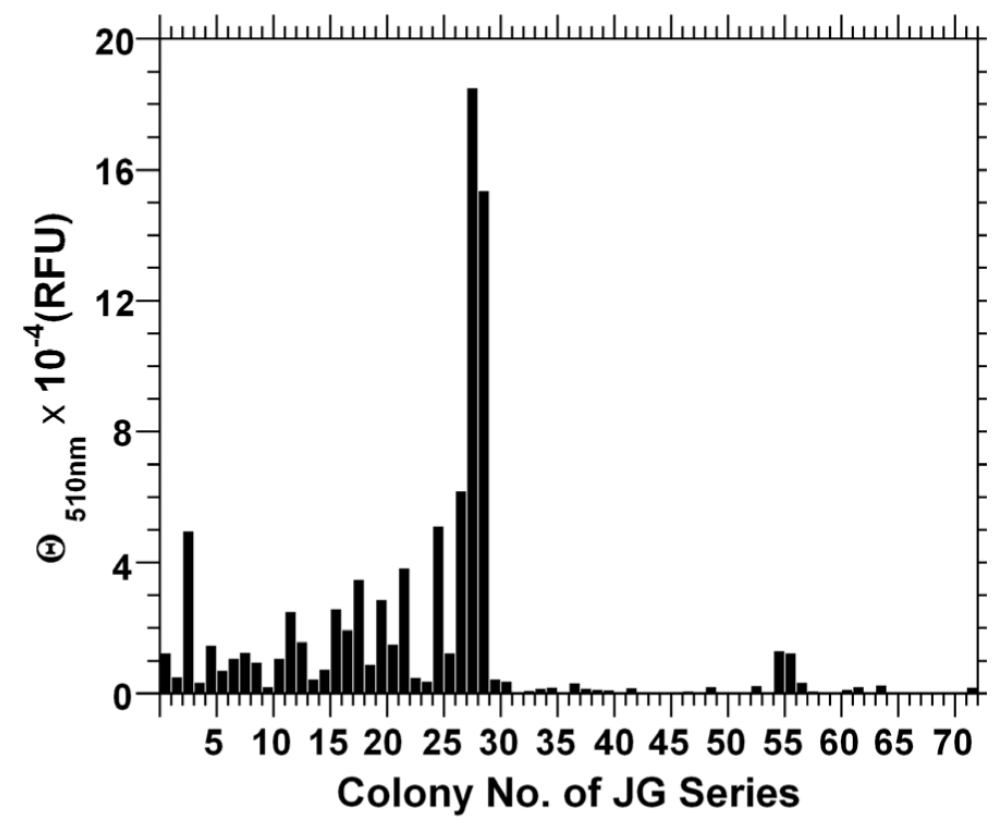

B

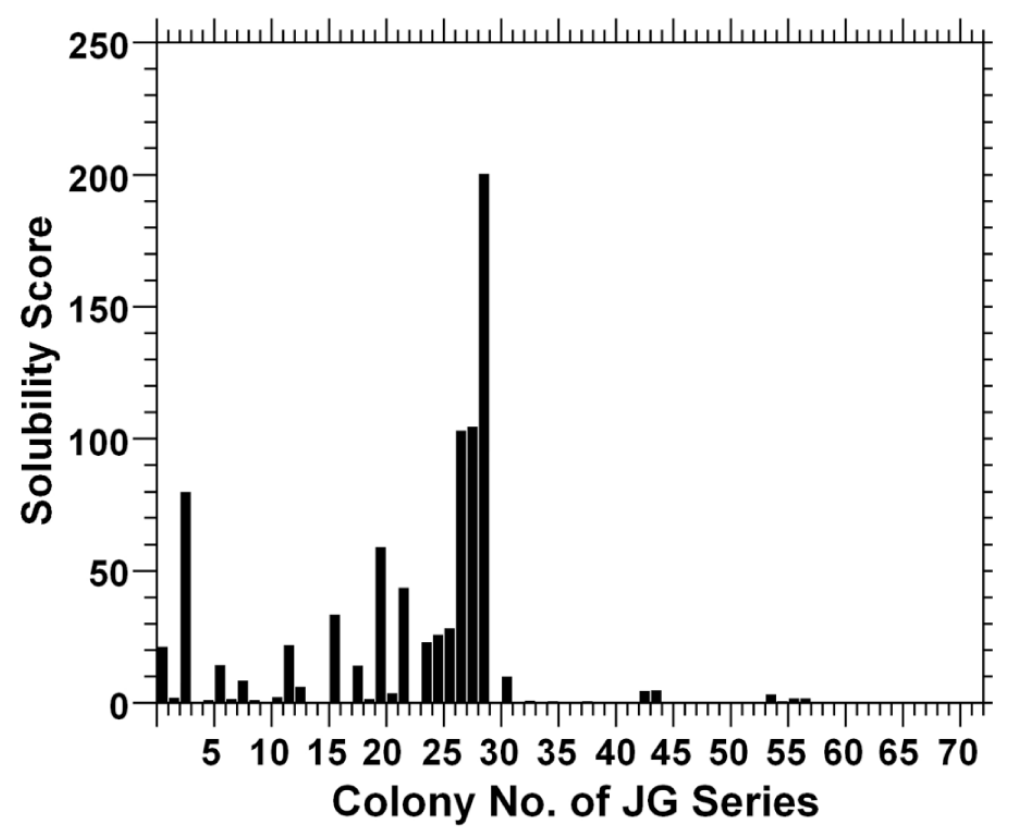

Figure 2.

Secondary library screening. Library screening of insert positive clones identified and isolated by FACS. Clones are screened by measurement of fluorescence emission at $510 \mathrm{~nm}$ (A) and solubility scores (B) for amplified cultures of 70 clones from both the Low and High Fluorescence libraries. Fluorescence emission of the induced library detects induced EGFP fusion proteins. The two-part solubility screen measures the expression of soluble His-tagged protein. 
Clone_5.6

Polaromonas_JS666_aldolase Silicibacter TM1040 racemase Marinobacter_ELB17_aldolase Polaromonas_CJ2_aldolase

Jannaschia_CCS1_racemase

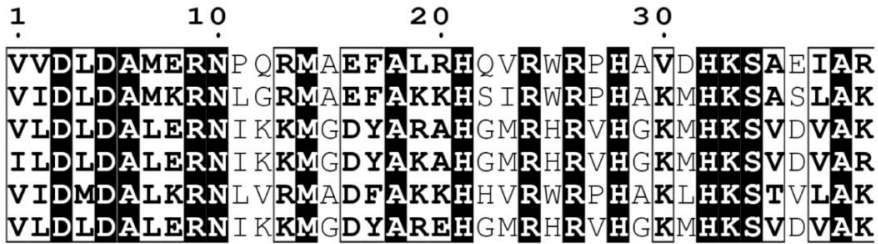

Clone_5.6

Polaromonas_JS666_aldolase

Silicibacter TM1040 racemase

Marinobacter_ELB17_aldolase

Polaromonas CJ2 aldolase

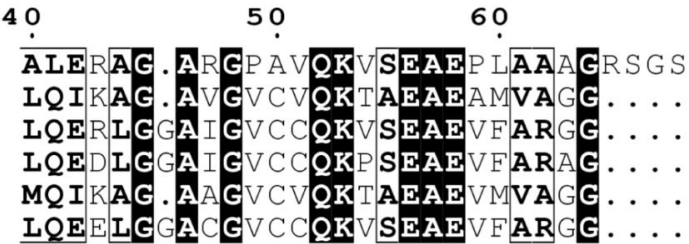

Figure 3.

Primary sequence alignment of clone 5.6 with the 5 closest homologous proteins identified by blastp search ${ }^{40}$ using ClustalW ${ }^{58}$ with default settings on the WWW service of the Euorpean Bioinformatics Institute (http://www.ebi.ac.uk/clustalw). Graphical image prepared using ESPript $2.2^{59}$. Identical residues are white, and conserved residues are boxed and bold. Sequences and fragment origins of clones 5.1, 5.6, 5.26 and 5.31. 


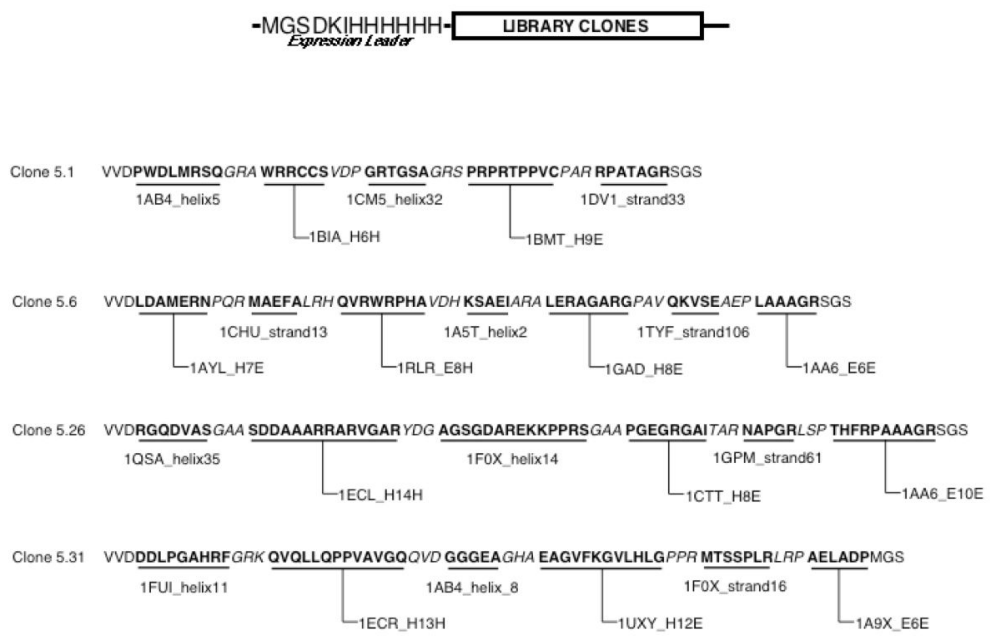

Figure 4.

Sequences and fragment origins of clones 5.1, 5.6, 5.26 and 5.31. The invariant sequence from the expression vector is represented schematically above each of the clones. The secondary structure elements are bold, underlined and labeled as to the original protein structures (Protein Data Bank code and fragment identifier). H/E-number-H/E defines the loop fragments by the type of secondary structure element joined (H-helix, E-strand) and the number reflects the number of residues in the loop. The inserted synthetic linkers from the Bbs I restriction sites are in italics. 


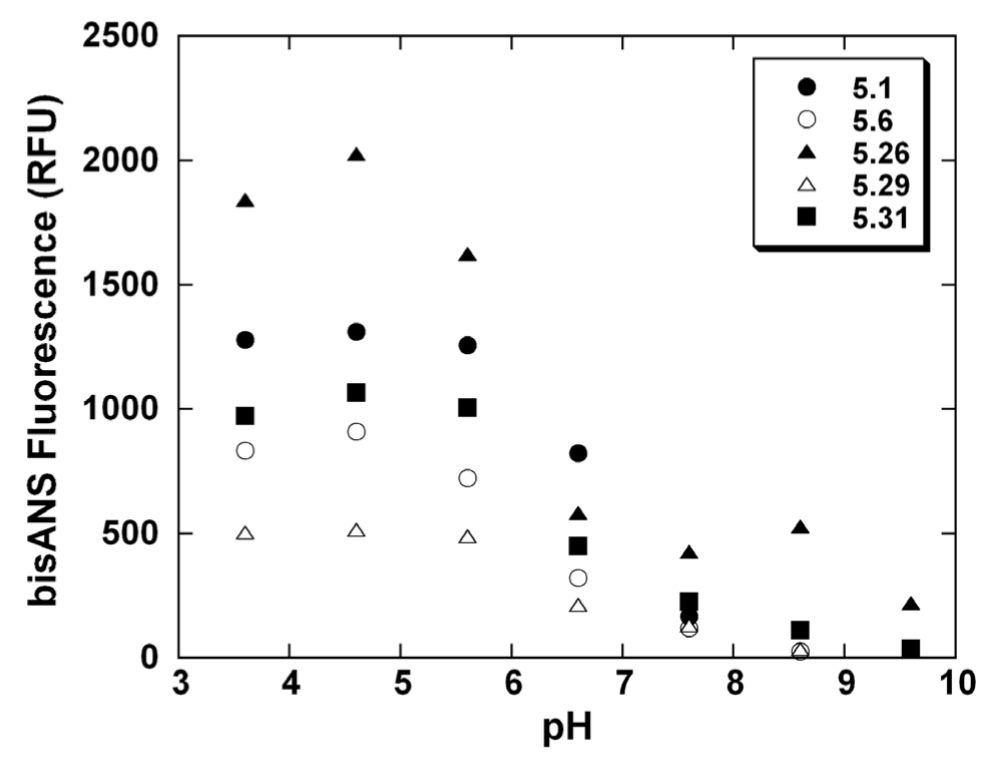

Figure 5.

bisANS binding as function of $\mathrm{pH}$ as measured by fluorescence emission at $495 \mathrm{~nm}$ for clones 5.1, 5.6, 5.26, 5.29 and 5.31: $2 \mu \mathrm{M}$ of each protein was combined with $15 \mu \mathrm{M}$ bisANS and incubated for $10 \mathrm{~min}$ at $25^{\circ} \mathrm{C}$ in acetate (pH 3.6, 4.6 and 5.6), phosphate (pH 6.6 and 7.6) and CHES (pH 8.6 and 9.6) buffers in triplicate prior to measuring fluorescence emission. 

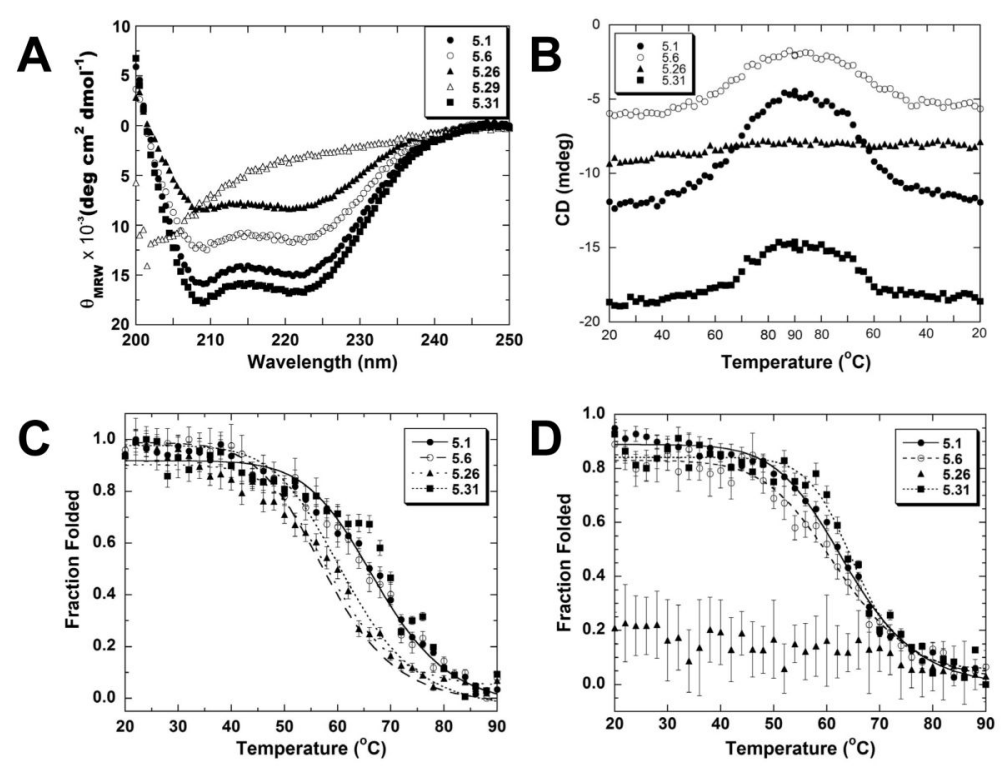

Figure 6.

Circular dichroism measurements. (A) Far-UV CD spectra for clones 5.1, 5.6, 5.26, 5.29 and 5.31. Spectra of each protein at $6 \mu \mathrm{M}$ collected at $25^{\circ} \mathrm{C}$ in PBS buffer averaged over five scans. (B) Thermal unfolding and refolding of clones 5.1, 5.6, 5.26 and 5.31 measured by loss of ellipticity at $222 \mathrm{~nm}$. (C) Thermal unfolding and (D) thermal refolding expressed as the fraction of protein folded at a given temperature. Spectra were collected with $6 \mu \mathrm{M}$ protein in PBS buffer from $20^{\circ} \mathrm{C}$ to $90^{\circ} \mathrm{C}$, and then from $90^{\circ} \mathrm{C}$ back to $20^{\circ} \mathrm{C}$. Clone 5.26 did not reversibly unfold. The data were fitted to a sigmoidal equation. 


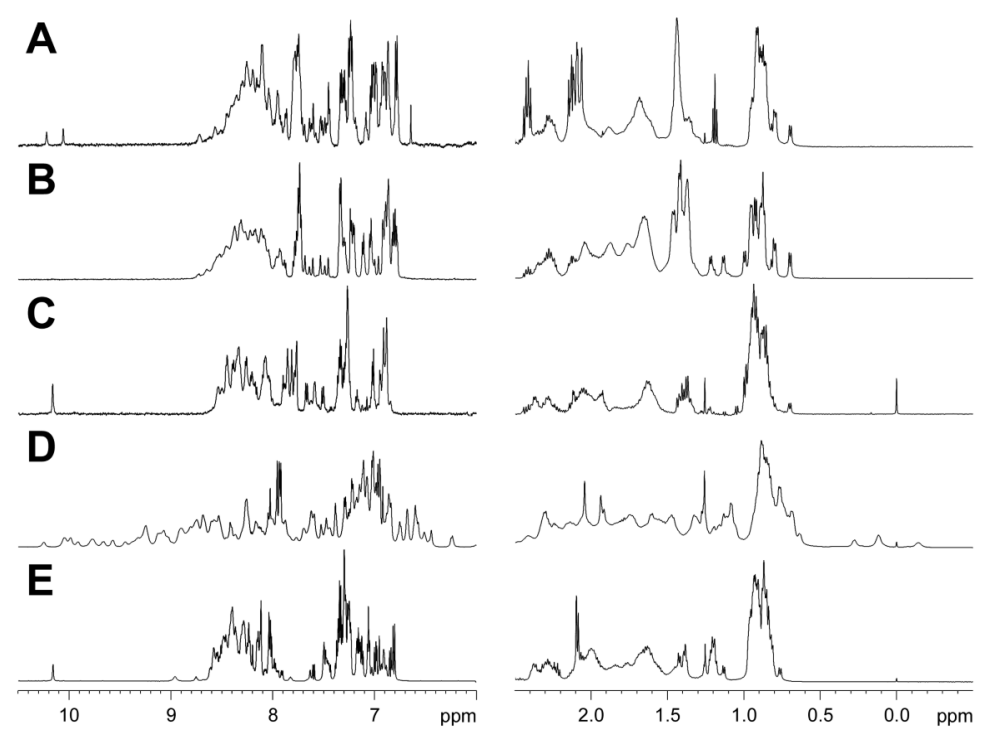

Figure 7.

One-dimensional NMR spectra of the amide regions (6 to $10.5 \mathrm{ppm}$ ) and methyl regions (-0.5 to $2.5 \mathrm{ppm}$ ) of clones $5.6(\mathrm{~A}), 5.26$ (B) and $5.31(\mathrm{C})$. For comparison, the spectra of folded FKBP12 and of unfolded FKBP12 in 6.7 M urea are shown in (D) and (E) respectively. Spectra were collected at $300 \mathrm{~K}$ as described in Materials and Methods. 
Table 1

5' and 3' Oligonucleotide Linker Sequences for Fragment Library.

\begin{tabular}{|c|c|c|}
\hline & Linker Name & Linker Sequence \\
\hline $5^{\prime}$ & Helix & GAGCTCGAAGACAGCGGCCGG \\
\hline $5^{\prime}$ & Loop $\mathrm{H}_{-}$ & GAGCTCGAAGACCGGCCGCT \\
\hline $5^{\prime}$ & Loop $\mathrm{S}_{-}$ & GAGCTCGAAGACTGGTGATC \\
\hline $5^{\prime}$ & Strand & GAGCTCGAAGACTGGCTAAC \\
\hline $5^{\prime}$ & $\begin{array}{l}\text { Terminator } \\
\text { Helix }\end{array}$ & $\begin{array}{l}\text { GAGCTCGTCGACCCATGGGATCTGATAAAATTCTTCCTTGA } \\
\text { TGTCTTCGAGCTC }\end{array}$ \\
\hline $5^{\prime}$ & $\begin{array}{l}\text { Terminator } \\
\text { Loop } \mathrm{H}_{-}\end{array}$ & $\begin{array}{l}\text { GAGCTCGTCGACCCATGGGATCTGATAAAATTCTTCGCCGA } \\
\text { TGTCTTCGAGCTC }\end{array}$ \\
\hline $5^{\prime}$ & $\begin{array}{l}\text { Terminator } \\
\text { Loop } \mathrm{S}_{-}\end{array}$ & $\begin{array}{l}\text { GAGCTCGTCGACCCATGGGATCTGATAAAATTCTTCGTGAA } \\
\text { TGTCTTCGAGCTC }\end{array}$ \\
\hline $5^{\prime}$ & $\begin{array}{l}\text { Terminator } \\
\text { Strand }\end{array}$ & $\begin{array}{l}\text { GAGCTCGTCGACCCATGGGATCTGATAAAATTCTTCGCTAA } \\
\text { TGTCTTCGAGCTC }\end{array}$ \\
\hline $3^{\prime}$ & Helix & GAGCTCGAAGACAGCGGCCGG \\
\hline $3^{\prime}$ & Loop_H & GAGCTCGAAGACCTCAAGGAG \\
\hline $3^{\prime}$ & Loop_S & GAGCTCGAAGACGTTAGCCAG \\
\hline $3^{\prime}$ & Strand & GAGCTCGAAGACGATCACCAG \\
\hline $3^{\prime}$ & $\begin{array}{l}\text { Terminator } \\
\text { Helix }\end{array}$ & $\begin{array}{l}\text { GAGCTCGAAGACCGGCCGCTGCCGGCCGATCGGGATCCG } \\
\text { AGCTC }\end{array}$ \\
\hline $3^{\prime}$ & $\begin{array}{l}\text { Terminator } \\
\text { Loop_H }\end{array}$ & $\begin{array}{l}\text { GAGCTCGAAGACCGCTTGCTGCCGGCCGATCGGGATCCG } \\
\text { AGCTC }\end{array}$ \\
\hline $3^{\prime}$ & $\begin{array}{l}\text { Terminator } \\
\text { Loop_S }\end{array}$ & $\begin{array}{l}\text { GAGCTCGAAGACCGGCTACTGCCGGCCGATCGGGATCCG } \\
\text { AGCTC }\end{array}$ \\
\hline $3^{\prime}$ & $\begin{array}{l}\text { Terminator } \\
\text { Strand }\end{array}$ & $\begin{array}{l}\text { GAGCTCGAAGACCGGTGACTGCCGGCCGATCGGGATCCG } \\
\text { AGCTC }\end{array}$ \\
\hline
\end{tabular}




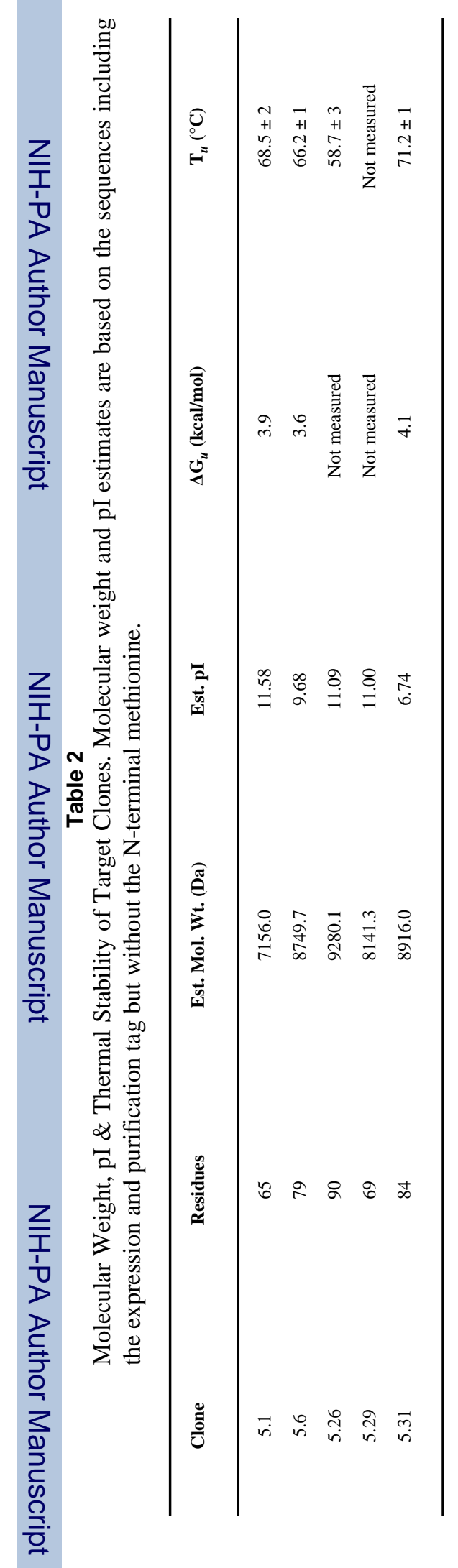

J Am Chem Soc. Author manuscript; available in PMC 2009 July 23. 